\title{
The Management of Teacher Professionalism Development Program at the Indonesian Public Primary School
}

\author{
Siti Romelah ${ }^{1 *}$, Happy Fitria ${ }^{2}$, Yessi Fitriani ${ }^{2}$
}

\author{
${ }^{1}$ PPS 1 Sumber Marga Telang Kabupaten Banyuasin \\ ${ }^{2}$ Universitas PGRI Palembang \\ *Corresponding author. E-mail: sitiromelah004@gmail.com
}

\begin{abstract}
This study analyzes the managmenet of teacher professional development programs, identifies the barriers and the solutions to those barriers. This is a descriptive qualitative research. The research site was in pubic primary school (PPS) 1 Sumber Marga Telang. This study involved the principal, and the informants are school operators, teachers, and students. Data collection methods used in this study were interview, observation, documentation. The collected data were analysed using qualitative data analysis techniques. It consists of data reduction, data presentation, and conclusions. This study identifies five activities in managing teacher professional development program: planning, organising, coordinating and controlling through supervision and coaching. This study finds some barriers in managing the program. The barriers include inadequate facilities and funding as well as less motivated teachers to develop their professionalism. To solve the problem, the school should provide learning facilities and funding needed.
\end{abstract}

Keywords: program management, teacher professionalism, teacher professionalism development

\section{INTRODUCTION}

Developing teacher professionalism is still a problem in Indonesia. The teacher development mainly aims to improve the quality of competence of a teacher. These include: pedagogical competencies, personality competencies, social competencies, and professional competencies [1].

Nowadays, professionalism is ademand for every profession, incl uding teacher profession. According to [1], professional teachers master a wide range of skills to teach. Professional teachers should have teaching experience, teaching skills faith, discipline, responsibilities, sbroad educational insights, managerial abilities, creativity, ability to understand the potentials, characteristics of their students, and to develop study plans and careers, to conductresearch and to develop curriculum. However, nowadays, with various reasons and backgrounds, teachers become busy so that many teachers do not understand and forget their duties and obligations as an educator. Many teachers are reluctant to improve their personal qualities with reading habits to broaden their horizons. On the other hand, human resources quality is crucial for improving the nation's quality of life. Regarding this, education has the task and obligation to provide learning to produce human resources that the nation needs
Professional is a term that refers to mental attitudes in the form of commitment from the members of the profession. While teacher professionalism reflects teachers' mental, attitude, and commitment to develop their competence so that their profession gives meaning [2].

Teacher professionalism is often associated with three critical factors, namely teacher competence, teacher certification, and teacher professional allowance. These three factors are the background that is thought to be closely related to the quality of education. Professional teachers can be proven by their competencies or abilities that will encourage the realization of processes and performance products that can improve education quality. Professional or competent teachers can also be proven by obtaining teacher certification and adequate professional benefits following regulations in Indonesia.

Development in education must be improved and needs to get serious attention from all parties to become a strong and advanced nation. Education is a process and means that affect the personal development of individuals in society. Education will achieve the objectives if the fulfillment of facilities, infrastructure, physical and non-physical, and education's organizational structure.

Education is a process of developing knowledge, skills, attitudeslof a person or group to educate 
human life through guidance, teaching, and training. Today, education is going through various changes forced by the community's demands and needs and is challenged to be responsive to local problems and rapid global change. These changes and problems include free markets, free labor, information development, science, technology, art, and culture.

A principal who succesfully in leads a school shows he is the one who are able to manage school resources efficiently and effectively. He has full authority and power to apply leadership style being considered to be effective and to use strategies develop his subordinates professionally. Thus it can be concluded that the success of the school is the success of the principal. In this case, the principal is one of key elements important to improve education quality.

Leadership is defined in differently including nature, personal behavior, influence on others, patterns of interaction, cooperation relationships between roles, and an administrative position. It is also about the legitimacy of influence to determine the direction and objectives, to provide guidance, and to create an atmosphere of work supporting the implementation of administration works and teaching and learning processes. The principal is considered to be an effective leader if he can carry out his leadership process to encourage, influence, and direct subordinates' activities and behavior towards a more advanced direction.

\subsection{Management}

According to Husaini Usman, the word "management" comes from the Latin word manus, which means hand, and agree, which means to do. Words as described, if combined into the verb "manager," which means to handle. The manager said this is translated into English in the form of verbs to manage, with noun management, and manager for people who do management activities. [3] defines management as a process of planning, organizing, directing, and controlling the organization's efforts and using other organizational resources to achieve the organization's goals that have been set.

Henry defines management asa process of utilizing raw materials and human resources in order to achieve the goals set. The process involves the organization, direction, coordination, and evaluation of people to achieve goals. In other words, the essence of management, according to Henry, is working through others to achieve different results. It integrates various resources and tasks to achieve various organizational objectives [4]. Meanwhile, according to [5], management is a typical process consisting of planning, organizing, and controlling actions carried out to determine and achieve predetermined goals through the utilization of organisational resources.

\subsection{Management Functions}

\section{Planning}

Planning is very important in management. A successful activity is usually an indication of careful planning. Any activities must begin with planning. It is the first step that everyone or every organization should do to achieve the expected goals.

\section{Organizing}

Organizing is an activity that seeks effective behavioral relationships between people to work together efficiently. According to [6], in his book entitled the foundation of education management, organizing is a process of dividing work into small tasks, imposing those tasks on people according to their abilities, and allocating human resources, as well as coordinating them together in the organization's goal of achieving goals.

\section{Coordinating}

Coordinating is needed in realizing the objectives of a private and public organization. Coordinating is directing, integrating, and coordinating elements of management and work elements of all its subordinates to achieve organizational goals. Coordination is the most crucial part among members or organizational unit whose work intersects. Coordinating integrates objectives and activities in separate units (departments or functional fields) to achieve the organization's objectives efficiently. If there is no coordination, individuals and departments will lose guidelines for their role in the organization.

\section{Controlling}

Controlling is the observation process of implementing all organizational activities to collect data. The aims is to identify the objectives and difficulties encountered in the program implementation. The function is to determine if the implementation of work follows the plan and prevents irregularities.

\subsection{Development}

Development is an effort to improve the technical, theoretical, conceptual, and moral abilities of staff. [7] states that development refers to staff and personnel matters a long-term educational process using systematic and organized procedures by which managers or leaders learn conceptual and theoretical knowledge for general purposes.

\subsection{Teacher professionalism}

Professionalism refers to mental attitudes in the form of commitment from the members of profession to realize and improve their professionals' quality. Meanwhile, teachers' professionalism is mirroring where the mental attitude and commitment to the realization and improvement of teacher competence's quality with 
all efforts and strategies and always develop their abilities by the demands of the times, so its existence always gives meaning (Rudi, 2014).. Professional teachers are qualified andcompetent teachers who are expected to be able to influence students' learning process, which will later produce better student learning achievements.

\section{METHODS}

This research uses a qualitative approach. Qualitative research aims to describe and analyze a phenomenon, event, social activity, attitude, belief, perception, and thinking of individual and group people. Qualitative research has two main objectives: the first to describe and reveal, and the second describes and explains [8].

\section{RESULTS AND DISCUSSION}

\section{Management of Teacher Professional Development Program at PPS 1 Sumber Marga Telang \\ The management of teacher professional} development programs at PPS 1 Sumber Marta Telang include planning, organizing, coordinating, and most recent to supervision functions. Planning is carried out by the principal gradually or periodically according to the school's needs through an initial meeting of the year, aiming to evaluate the program in the previous year. Teacher professional development is an important program because teachers are among the main factors of successful education in schools. In organizing, the principal of PPS 1 Sumber Marga Telang, provides opportunities for teachers to attend seminars and training to enhance their insights and knowledge..

There are $\mathrm{s}$ wide range of teacher professional development programs. These include providing learning facilities such as such as learnig media andWiFi. workshop, training related to learning, information technology, visits to other schools, pursuing master' degree, etc. Facilities such as learning media and WIFI are needed to support the implementation of those programs. However, inPPS 1 Sumber Marga Telang, there is also no need to implement the above because of limited funds for the purchase of WiFi, LCD, or projector. Furthermore, benchmarking has never been done, including continuing master's studies. Only some teachers have a passion for going through it. Also, training activities and workshops are rarely followed by teachers. Some only follow programs carried out by the government, so it is external.

2. Barriers in Managing Teacher Professional Development Programs in PPS1 Sumber Marga Telang

PPS 1 Sumber Marga Telang, experiences problems or obstacles in the process of developing teacher professionalism. The obstacles include:Schools lack of money to finance teacher professional development.

1. The difficulty o to determine the relevant development program tor teachers.

2. Lack of encouragement from the principal for teachers to develop their professionalisme.

3. Strategies to deal with the barriers of managing teacher professional development programs

In facing the barriers, the principal, as the leader, took several steps as follows.

1. The principal provides guidance and direction to all teachers to participate in the teacher development program.

2. Facilities and infrastructure should be available.Teachers are expected to have their own laptop and the school need to provide an internet connection and LCD.

3. The principal provides opportunities for all teachers to participate in teacher professional development activities such as seminars, workshops, opportunities to continue master's studies, etc.

\section{CONCLUSION}

Teacher professional development programs PPS 1 Sumber Marga Telang has been managed. The principals plan, organise, coordinate, and control the program. They provide teachers opportunities to develop their competencies through training, seminars, workshops, MGMP, and further studies for teachers' professionalism.

The obstacles experienced by PPS 1 Sumber Marga Telang in managing teacher professionalism development programs include the lack of infrastructure and available funding. Teachers who want to develop learning methods are disturbed by the absence of LCD media in schools. So the principal must be good at finding or raising funds to provide learning facilities needed.

The solution to overcome the obstacles at PPS 1 Sumber Marga Telang is that teachers can participate in teacher professional development programs organized by the government or other educational institutions. All teachers are expected to be more empowered to develop their skills by themselves by reading books, electronic media to keep the information up to date, and doing class action research or writing books dedicated to schools.

\section{REFERENCES}

[1]. Patrescu, A. M. (2015). Innovation aspect of the professional Development Program 
Dedicated to science teacher, procelia social and behavional Google Scholar.

[2]. Rudi. (2014). Peranan Profesionalisme Guru dalam Meningkatkan Mutu Pendidikan.

[3]. Stoner, A. M. (2014). Manajemen. IAIN Walisongo.

[4]. Wibowo, A. (2013). Manajemen Pendidikan Karakter di Sekolah. Yogyakarta: Pustaka Pelajar.
[5]. Sukarna. (2011). http//www.studi manajemen.com.

[6]. Nanang, F. (2019). Landasan Manajemen Pendidikan. Bandung: Remaja Rosda Karya.

[7]. Rohmat. (2012). Tekhnologi Pembelajaran, Yogyakarta: CV Budi Utama.

[8]. Sukmadinata, N. S. (2013). Metode Penelitian Pendidikan. Bandung. PT Remaja Rosdakarya. 